\title{
Dynamics of Mango Hopper Population under Ultra High Density Planting
}

\author{
A.U. Chaudhari ${ }^{*}$, S. Sridharan ${ }^{1}$, K. Soorianathasundaram ${ }^{2}$ and S.D. Sundar Singh $^{3}$ \\ ${ }^{1}$ Department of Agricultural Entomology, Centre for Plant Protection Studies, Tamil Nadu \\ Agricultural University, Coimbatore - 641 003, Tamil Nadu, India \\ ${ }^{2}$ Department of Fruit Crops, HC \&RI, Tamil Nadu Agricultural University, \\ Coimbatore - 641 003, Tamil Nadu, India \\ ${ }^{3} \mathrm{R} \&$ D farm, Jain Irrigation Systems Limited, Udumalpet-642154, Tamil Nadu, India \\ *Corresponding author
}

\section{A B S T R A C T}

Field observation at weekly intervals on the occurrence of mango hopper population under Ultra high density planting system of mango was carried out at R \& D farm, Jain Irrigation

Keywords

Population, Dynamics, Mango hopper, Ultra high density.

Article Info

Accepted:

17 September 2017

Available Online:

10 November 2017
Systems Limited, Udumalpet, Tamil Nadu during 2014. The incidence of hopper population was noted from $4^{\text {th }}$ week of January which reaches its peak ( 80 hoppers $/ 20$ panicles) during fourth week of February corresponding with $8^{\text {th }}$ standard week. The hopper population declined from second week of March which disappeared during second week of May. Reoccurrence of hopper population was observed in first week of September with peak population of 4.8 hoppers $/ 20$ panicles in vegetative phase after pruning. Thus two distinct peaks were observed during crop period, one in reproductive and another in vegetative phase. Maximum temperature, morning RH, evaporation and sunshine hours influenced the hopper infestation positively but not significant whereas minimum temperature, afternoon $\mathrm{RH}$, rainfall and wind speed showed non-significant negative correlation. The regression analysis also indicated the influence of crop phenology with hopper incidence as compared to abiotic factors prevailed during 2014 at R \&D farm, JISL, Udumalpet, TN.

\section{Introduction}

Mango (Mangifera indica Linn.) is very important fruit crop of India and ranks $1^{\text {st }}$ in world mango production with production of 18.43 Million Tonnes in 2014 (NHB, 2015). The major biotic constrains that affect the production and quality of mango is mainly due to the incidence of about 400 insects pests (Tandon and Verghese, 1985) Among these various pests, mango hopper [Amritodus atkinsoni (Lethierry), Idioscopus clypealis (Lethierry) I.niveosparsus (Lethierry) and $I$. nitidulus (Walker)] is a serious pest of mango at flowering and fruiting stages resulting in yield loss up to $100 \%$ (Rahman and Kuldeep, 2007). Likewise, Sohi and Sohi (1990) reported that leaf hoppers are the most serious among the pests of mango causing $20-100$ per cent loss of inflorescence and thereby the yield. In mango, the hopper activity coincides with maximum emergence of inflorescence and new shoots (Zagade and Chaudhari, 2010). Both nymphs and adults suck sap from tender leaves, buds, flowers, flower stalk and fruits. Severely infested leaves become curled 
and inflorescence gets dried (Kannan and Venugopal, 2006). Hoppers also excrete honey dew which encourages the development of sooty mould interfering with the normal photosynthetic activity of the plant. Ultra High Density planting (UHDP) of mango is new concept which accommodates 500 to 674 plants per acre as against 40 and 160 plants is traditional and high density planting respectively. Many workers have reported the population dynamics of mango hopper in different regions of India but information pertaining to its development in relation to canopy regulated UHDP is lacking. Hence, the population buildup of mango hopper under ultra-high density planting of mango was observed during 2014 at R \& D farm, Jain Irrigation Systems Limited, Udumalpet, Tamil Nadu.

\section{Materials and Methods}

The present study on dynamics of mango hopper population was carried out in five year old Ultra high density planting of mango with the spacing of $3 \mathrm{~m} \times 2 \mathrm{~m}$ in R \& D farm of Jain Irrigation Systems Limited at Udumalpet, Tamil Nadu from January to December, 2014. Twenty trees were selected for the study and maintained without the use of any pesticides. The crop was observed at weekly intervals throughout the year for the incidence of mango hopper.

Observations were recorded during morning hours $08.00 \mathrm{hrs}$ to $9.00 \mathrm{hrs}$. For each sampling, five random panicles/ inflorescence were selected from the four directions of the canopy viz. east, west, north, south. Thus from each tree, 20 numbers of sampling units were observed as per manual for mango pest surveillance (NICRA, 2012). The live nymphs and adults were observed and noted throughout the study period. The height of the tree in UHDP orchard maintained at 6 feet enables visual observation of hopper. The observations were tabulated as total hoppers per 20 panicles.

The weather parameters for the study period viz. maximum and minimum temperature $\left({ }^{\circ} \mathrm{C}\right)$,relative humidity morning and afternoon(\%),evaporation (mm),rainfall $(\mathrm{mm})$, wind speed $(\mathrm{km} / \mathrm{hr})$ and sunshine hours (hrs) of the experiment site were collected from the R \& D farm, Udumalpet. This data was used for the correlation and regression analysis.

\section{Statistical analysis}

Correlation between the pest population and weather parameters viz., maximum temperature, minimum temperature, morning relative humidity, afternoon relative humidity, evaporation, rainfall, wind speed and sunshine hours, was assessed using Carl Pearson's correlation analysis. Statistical analysis of the data was carried out by using the SPSS software

\section{Results and Discussion}

\section{Population dynamics of mango hopper}

The monitoring of hopper population indicated that the mango hopper started appearing in fourth standard week (i.e. fourth week of January) with 1.05 hopper/20 panicles which recorded a temperature maximum of $32.14^{\circ} \mathrm{C}$ and minimum of $17^{\circ} \mathrm{C}$ while the morning relative humidity and afternoon relative humidity registered was 77.43 and $48.71 \%$ respectively (Table 1 ). Further, the hopper population gradually increased to $4.80,23.05$ and 49.45 per 20 panicles in $5^{\text {th }} 6^{\text {th }}$ and $7^{\text {th }}$ standard week respectively. The mean population of hopper reached its peak during 8th (80.80 hopper/20 panicles) and $9^{\text {th }}$ (73.50 hoppers/20 panicles) standard metrological week merging with fourth week of February and first week of 
March, 14 (Fig. 1). During the period of peak occurrence of hopper, the temperature maximum $\left(32.93-34.29^{\circ} \mathrm{C}\right)$ and minimum $\left(21.00-21.71^{\circ} \mathrm{C}\right)$ recorded were moderate as against $39.14^{\circ} \mathrm{C}$ and $25.29^{\circ} \mathrm{C}$ recorded respectively as maximum and minimum prevailed during other months.

The hopper population decreased drastically from March II week which was absent in second week of May. The hopper population observed to develop slowly and steadily from III week of August with 1.90 hopper per 20 panicles which escalated from 2.15 to 4.8 hoppers per 20 panicles during vegetative phase (off season) corresponding to $34^{\text {th }}$ to $39^{\text {th }}$ standard week. The maximum and minimum temperature prevailed during the period ranged between $\left(31.36^{\circ} \mathrm{C}\right.$ to $\left.34.14^{0} \mathrm{C}\right)$ and $\left(22.50^{\circ} \mathrm{C}\right.$ to $\left.23.57^{\circ} \mathrm{C}\right)$ respectively. The hopper population declined subsequently from $49^{\text {th }}$ SMW up to $52^{\text {nd }}$ SMW. Dalvi and Dumbre (1994) studied the seasonal incidence of mango hoppers in Dapoli, Maharashtra and reported that mango hopper A. atkinsoni and/ Nieveosparsus escalated from mid-December onwards as the pest multiplied profusely on flower panicles and reached a peak in the third week of March and second week of February, respectively followed by gradual decline until the end of March or early April. This finding was similar to the present finding. Ashok Kumar et al., (2014) who recorded considerable reduction in the hopper population from April to May at Jhansi (U.P.) was also in line with the present findings. Thus two distinct peaks on hopper population one in reproductive phase in fourth week of February with 80 hoppers per 20 panicles and another at vegetative phase in first week of September with 4.80 hoppers $/ 20$ panicles was observed (Fig. 1). Similar peaks in reproductive phase and vegetative phase were also observed by Gundappa et al., (2015) at Lucknow (U.P.).

\section{Association of mango hopper population with abiotic factors}

The correlation coefficients between abiotic factors and mango hopper showed nonsignificant relationship (Table 2). Kannan and Rao (2006) related the hopper population in Tirupati region of Andhra Pradesh with abiotic factors wherein, they observed positive correlation with maximum temperature $(\mathrm{r}=0.3406)$ and negative correlation with minimum temperature $(\mathrm{r}=$ 0.2038). The positive correlation with maximum temperature and negative correlation with minimum temp was also reported by Pushpalatha (2008).These findings were similar to the present observations.

Fig.1 Population dynamics of mango hoppers in Ultra High Density orchards at, Udumalpet, Tamil Nadu

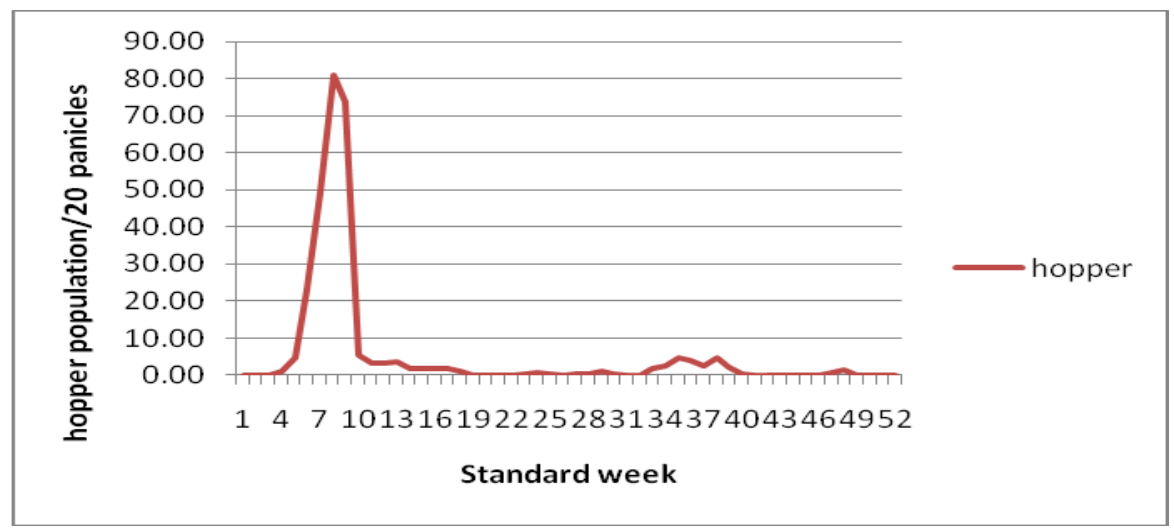


Table.1 Population of mango hopper during 2014 at R\&D farm, JISL, Udumalpet

\begin{tabular}{|c|c|c|c|c|c|c|c|c|c|c|}
\hline \multirow[t]{2}{*}{$\begin{array}{l}\text { Standard } \\
\text { Week }\end{array}$} & \multirow{2}{*}{$\begin{array}{l}\text { Period of } \\
\text { Obser- } \\
\text { vation }\end{array}$} & \multirow{2}{*}{$\begin{array}{l}\text { Hopper } \\
/ 20 \\
\text { panicles }\end{array}$} & \multicolumn{2}{|c|}{$\begin{array}{l}\text { Temperature } \\
\left({ }^{\circ}\right)\end{array}$} & \multicolumn{2}{|c|}{$\begin{array}{l}\text { Relative Humidity } \\
(\%)\end{array}$} & \multirow[t]{2}{*}{$\begin{array}{l}\text { Rainfall } \\
(\mathrm{mm})\end{array}$} & \multirow{2}{*}{$\begin{array}{l}\text { Evapora- } \\
\text { Tion } \\
(\mathrm{mm})\end{array}$} & \multirow{2}{*}{$\begin{array}{l}\text { Wind } \\
\text { Speed } \\
\mathrm{km} / \mathrm{hr}\end{array}$} & \multirow[t]{2}{*}{$\begin{array}{l}\text { Sun } \\
\text { Shine } \\
\text { (hrs) }\end{array}$} \\
\hline & & & Maxi- & mini- & Morning & Afternoon & & & & \\
\hline 1 & Jan,14 & 0.00 & 32.21 & 16.50 & 75.00 & 55.43 & 0.00 & 3.64 & 0.59 & 6.64 \\
\hline 2 & & 0.00 & 31.36 & 17.79 & 80.57 & 52.71 & 0.14 & 3.94 & 0.82 & 6.14 \\
\hline 3 & & 0.00 & 32.57 & 18.14 & 78.57 & 45.29 & 0.00 & 5.86 & 0.66 & 7.00 \\
\hline 4 & & 1.05 & 32.14 & 17.00 & 77.43 & 48.71 & 0.00 & 5.43 & 0.71 & 7.36 \\
\hline 5 & Feb,14 & 4.80 & 32.36 & 16.36 & 76.29 & 44.71 & 0.00 & 5.57 & 0.70 & 8.25 \\
\hline 6 & & 23.05 & 34.50 & 14.57 & 68.29 & 31.00 & 0.00 & 7.50 & 0.72 & 9.14 \\
\hline 7 & & 49.45 & 33.71 & 21.71 & 79.00 & 47.86 & 0.00 & 4.29 & 0.99 & 5.93 \\
\hline 8 & & 80.80 & 32.93 & 21.00 & 77.57 & 46.57 & 0.00 & 5.29 & 0.74 & 5.89 \\
\hline 9 & March,14 & 73.50 & 34.29 & 21.71 & 82.57 & 44.86 & 1.64 & 5.71 & 0.83 & 6.39 \\
\hline 10 & & 5.40 & 33.43 & 21.71 & 80.29 & 48.43 & 0.07 & 4.14 & 0.72 & 5.00 \\
\hline 11 & & 3.25 & 34.71 & 18.14 & 67.00 & 37.00 & 0.00 & 7.14 & 1.17 & 7.36 \\
\hline 12 & & 3.20 & 37.50 & 21.29 & 70.00 & 35.71 & 0.00 & 8.07 & 1.06 & 7.18 \\
\hline 13 & April,14 & 3.50 & 38.57 & 18.71 & 63.29 & 31.00 & 0.00 & 8.21 & 1.21 & 7.11 \\
\hline 14 & & 1.90 & 39.14 & 24.00 & 74.71 & 29.43 & 0.07 & 9.00 & 1.73 & 6.96 \\
\hline 15 & & 1.90 & 38.36 & 23.71 & 67.43 & 25.29 & 0.93 & 8.00 & 2.01 & 6.36 \\
\hline 16 & & 1.65 & 38.57 & 24.71 & 72.57 & 31.14 & 0.21 & 7.57 & 1.90 & 6.81 \\
\hline 17 & & 1.90 & 38.57 & 25.14 & 73.29 & 40.86 & 4.50 & 6.14 & 1.60 & 4.50 \\
\hline 18 & May,14 & 1.00 & 36.64 & 24.29 & 71.29 & 44.86 & 2.86 & 5.21 & 1.64 & 5.21 \\
\hline 19 & & 0.00 & 33.43 & 23.14 & 72.57 & 49.43 & 0.93 & 4.50 & 3.34 & 4.89 \\
\hline 20 & & 0.00 & 36.64 & 23.43 & 70.43 & 34.29 & 0.14 & 6.43 & 3.58 & 7.64 \\
\hline 21 & & 0.00 & 36.64 & 24.00 & 68.00 & 40.71 & 2.14 & 7.43 & 4.27 & 7.21 \\
\hline 22 & June,14 & 0.00 & 35.29 & 23.14 & 71.71 & 40.57 & 1.79 & 6.21 & 4.34 & 8.86 \\
\hline 23 & & 0.50 & 35.21 & 24.57 & 66.57 & 41.14 & 0.00 & 8.86 & 6.44 & 7.54 \\
\hline 24 & & 0.85 & 34.86 & 24.71 & 65.57 & 39.71 & 0.00 & 8.79 & 7.08 & 8.68 \\
\hline 25 & & 0.20 & 33.14 & 24.43 & 66.14 & 50.14 & 0.36 & 8.00 & 7.12 & 4.43 \\
\hline 26 & July, 14 & 0.00 & 35.36 & 23.64 & 66.00 & 45.43 & 0.93 & 8.43 & 4.66 & 6.43 \\
\hline 27 & & 0.40 & 34.79 & 25.29 & 61.71 & 38.71 & 0.79 & 8.43 & 6.52 & 7.79 \\
\hline 28 & & 0.45 & 31.07 & 22.71 & 74.14 & 64.43 & 0.14 & 5.43 & 6.79 & 3.14 \\
\hline 29 & & 1.00 & 31.71 & 24.14 & 64.14 & 57.00 & 0.21 & 7.86 & 8.57 & 3.86 \\
\hline 30 & & 0.35 & 32.14 & 22.86 & 71.71 & 56.00 & 0.00 & 6.93 & 7.57 & 4.54 \\
\hline 31 & Aug,14 & 0.00 & 31.29 & 22.86 & 76.43 & 57.57 & 1.36 & 5.36 & 7.84 & 3.36 \\
\hline 32 & & 0.00 & 28.14 & 23.57 & 71.71 & 54.43 & 0.00 & 4.86 & 6.31 & 2.04 \\
\hline 33 & & 1.90 & 33.71 & 22.57 & 73.57 & 44.57 & 14.00 & 5.71 & 4.47 & 6.86 \\
\hline 34 & & 2.45 & 32.50 & 22.43 & 84.00 & 54.57 & 0.93 & 4.57 & 2.82 & 3.89 \\
\hline 35 & Sept,14 & 4.80 & 31.36 & 22.50 & 75.86 & 54.71 & 0.07 & 4.57 & 5.19 & 3.46 \\
\hline 36 & & 4.15 & 32.64 & 23.43 & 71.29 & 48.43 & 0.00 & 6.00 & 5.46 & 4.96 \\
\hline 37 & & 2.70 & 33.57 & 23.14 & 65.29 & 39.57 & 0.00 & 7.43 & 5.81 & 7.11 \\
\hline
\end{tabular}




\begin{tabular}{|l|l|l|l|l|l|l|l|l|l|l|}
38 & & 4.60 & 34.14 & 23.57 & 67.57 & 41.00 & 1.07 & 6.57 & 4.84 & 4.89 \\
\hline 39 & & 2.15 & 32.93 & 22.50 & 86.14 & 54.14 & 5.29 & 3.50 & 1.14 & 4.96 \\
\hline 40 & Oct,14 & 0.35 & 32.79 & 22.29 & 77.86 & 49.57 & 0.57 & 4.57 & 1.73 & 4.57 \\
\hline 41 & & 0.00 & 34.00 & 23.57 & 72.86 & 50.86 & 2.29 & 4.57 & 2.82 & 4.61 \\
\hline 42 & & 0.00 & 27.57 & 21.07 & 93.57 & 80.00 & 34.21 & 0.86 & 0.26 & 1.57 \\
\hline 43 & & 0.00 & 30.14 & 20.86 & 91.00 & 70.29 & 12.29 & 1.93 & 0.34 & 4.00 \\
\hline 44 & Nov,14 & 0.00 & 30.50 & 21.86 & 84.71 & 64.57 & 0.07 & 2.21 & 0.39 & 2.57 \\
\hline 45 & & 0.00 & 33.29 & 20.29 & 80.00 & 46.57 & 6.29 & 3.50 & 0.59 & 5.89 \\
\hline 46 & & 0.15 & 29.29 & 21.00 & 87.57 & 66.00 & 0.93 & 1.71 & 0.36 & 2.64 \\
\hline 47 & & 0.80 & 29.71 & 19.86 & 84.86 & 64.29 & 0.00 & 1.86 & 0.41 & 1.93 \\
\hline 48 & Dec,14 & 1.40 & 27.36 & 20.21 & 85.71 & 73.57 & 0.07 & 1.43 & 0.71 & 0.36 \\
\hline 49 & & 0.00 & 31.21 & 18.29 & 78.57 & 54.29 & 0.00 & 3.99 & 0.34 & 5.14 \\
\hline 50 & & 0.00 & 30.21 & 20.29 & 85.71 & 60.43 & 1.64 & 3.29 & 0.40 & 2.36 \\
\hline 51 & & 0.00 & 27.86 & 19.79 & 90.57 & 72.43 & 2.36 & 1.61 & 0.25 & 1.43 \\
\hline 52 & & 0.00 & 29.56 & 20.38 & 85.00 & 59.00 & 0.06 & 2.25 & 0.39 & 2.16 \\
\hline
\end{tabular}

Table.2 Influence of weather parameters on seasonal abundance of mango hopper in 2014

\begin{tabular}{|l|c|}
\hline \multirow{2}{*}{ Variables } & Correlation coefficient \\
\cline { 2 - 2 } & Hoppers \\
\hline Maximum temperature $\left(\mathrm{T}_{\max }\right)\left({ }^{\circ} \mathrm{C}\right)$ & 0.072 \\
\hline Minimum temperature $\left(\mathrm{T}_{\min }\right)\left({ }^{\circ} \mathrm{C}\right)$ & -0.104 \\
\hline Relative humidity $(\%)$ Morning & 0.087 \\
\hline Relative humidity $(\%)$ Afternoon & -0.131 \\
\hline Rainfall $(\mathrm{mm})$ & -0.85 \\
\hline Evaporation $(\mathrm{mm} /$ day $)$ & 0.026 \\
\hline Wind speed $(\mathrm{km} / \mathrm{hr})$ & -0.203 \\
\hline Sunshine hours $(\mathrm{hrs})$ & 0.154 \\
\hline
\end{tabular}

Table.3 Multiple linear regression analysis for the prediction of seasonal abundance of mango hopper

\begin{tabular}{|c|c|c|}
\hline \multirow[b]{2}{*}{ Variables } & Regression coefficient & \multirow[b]{2}{*}{$\mathbf{R}^{2}$} \\
\hline & Hoppers (b) & \\
\hline Intercept & 6.838 & \multirow{9}{*}{0.158} \\
\hline Maximum temperature $\left(\mathrm{T}_{\max }\right)\left({ }^{\circ} \mathrm{C}\right)$ & -3.542 & \\
\hline Minimum temperature $\left(\mathrm{T}_{\min }\right)\left({ }^{\circ} \mathrm{C}\right)$ & 2.085 & \\
\hline Relative humidity (\%)Morning & 0.888 & \\
\hline Relative humidity (\%) Afternoon & -0.411 & \\
\hline Rainfall $(\mathrm{mm})$ & -0.364 & \\
\hline Evaporation (mm/day) & 4.026 & \\
\hline Wind speed $(\mathrm{km} / \mathrm{hr})$ & -2.937 & \\
\hline Sunshine hours (hrs) & -2.129 & \\
\hline
\end{tabular}


The afternoon relative humidity showed nonsignificant negative relationship $(r=-0.131)$ with hopper population. Kannan and Rao (2006) also reported insignificant positive correlation of hopper population with morning $\mathrm{RH}$ and significant negative correlation with evening RH at Tirupati. Zagade and Chaudhari (2010) similarly reported that hopper population was inversely related to relative humidity and minimum temperature.

The multiple regression analysis of weather factors with the hopper population arrived at $\mathrm{R}^{2}$ value of 0.158 (Table 3) which is insignificant but indicated the influence of weather factors to an extent of 15 percent. This can be attributed to the occurrence of hopper mainly during flowering and new shoot initiation merging with the crop phenology rather than the abiotic factors. The absence of hopper population during other months of static crop period might have contributed to the insignificant relationship of abiotic factors. Generally, the hopper population varies with varying crop growth in different regions and weather factors are not homogeneous every year which may vary influencing their significance. Therefore, the critical observations of meteorological factors and hopper population for several years under controlled canopy condition shall project a more reliable.

\section{References}

Dalvi, C.S., and Dumbre, R.B.1994. Breeding and seasonal incidence of mango hoppers, Bull Ent. 35(1-2): 1-10.

Gundappa, Adak, T., and Balaji, R. 2015. Variability of thermal indices and peak mango hoppers incidence under subtropical condition. J. Agr. Phys. 15 (2):150-156.
Kannan, M., and Rao, N.V. 2006. Ecological studies on mango hopper, Amritodus atkinsoni in Andhra Pradesh as a basis for IPM. Crop Res.32: 235-238.

Kumar, A., Swami V.P., and Amrita Singh, A. 2014. To Study on the population Dynamics of Mango Hopper Amritodus atkinsoni leth. Res J. Chem. Environ. Sci. 2 (3): 48-51.

NHB. Indian Horticulture Database-2014 published by National Horticulture Board, Ministry of Agriculture, Government of India. 2015, 302.

NICRA team of Mango Pest Surveillance.2012. Manual for Mango Pest Surveillance. Jointly published by National Centre for Integrated Pest Management, New Delhi, ICAR Research Complex for Eastern Region, Research Centre, Ranchi, Central Research Institute for Dry land Agriculture, Hyderabad, and Central Institute for Subtropical Agriculture, Lucknow. 39 pp.

Pushpalatha, S., Kathirvelu, C., and Nachiappan, R.M. 2008. Correlation of seasonal incidence of mango hopper, Amritodes atkinsoni and weather parameters on certain varieties of mango. Indian J. Trop. Biodiver. 15: 81-83.

Rahman, S.K., and Kuldeep, M.A. 2007. Mango hoppers: Bioecology and management. A Review. Agricultural Reviews.28:49-55

Sohi, A.S., and Sohi, A.S. 1990. Mango leafhoppers (Homoptera: Cicadellidae) -A review. J. Insect Sci. 3:1-12.

Tandon, P.L., and Verghese, A.1985. World list of insects, mites and other pests of mango. Technical Document Indian Institute of Horticultural Research, Bangalore, India.5: 22.

Zagade, M.V., and Chaudhari, J.N. 2010. Impact of meteorological parameters on population dynamics of mango hopper in high rainfall zone of Konkan region. J. Agrometeorol.12 (1): 111-113.

\section{How to cite this article:}

Chaudhari, A.U., S. Sridharan, K. Soorianathasundaram and Sundar Singh, S.D. 2017. Dynamics of Mango Hopper Population under Ultra High Density Planting. Int.J.Curr.Microbiol.App.Sci. 6(11): 2206-2211. doi: https://doi.org/10.20546/ijcmas.2017.611.261 